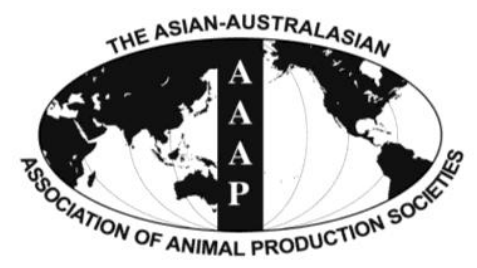

Asian-Aust. J. Anim. Sci.

Vol. 25, No. $6: 824$ - 831

June 2012

www.ajas.info

http://dx.doi.org/10.5713/ajas.2011.11462

\title{
Effect of Cattle Breed on Meat Quality, Muscle Fiber Characteristics, Lipid Oxidation and Fatty Acids in China
}

\author{
Xiangxue Xie, Qingxiang Meng, Zhenliang Cui and Liping Ren* \\ State Key Laboratory of Animal Nutrition, College of Animal Science and Technology, \\ China Agricultural University, Beijing 100193, China
}

\begin{abstract}
The objective was to compare meat quality, muscle fiber characteristics, lipid oxidation and fatty acids of Limousin (LIM), Simmtental (SIM), Luxi (LX), Qinchuan (QC) and Jinnan (JN) offered the same diet in China. After finishing, eight bulls from each breed were randomly selected for slaughter at 18.5 months old. Longissimus dorsi (ld) muscle was taken from the carcass for meat quality evaluations. Breed had little effect on most of meat and fat color parameters except for Hue and $b^{*}$ in which QC had lower values. LIM showed higher $\mathrm{pH}(24 \mathrm{~h})$ and better water holding capacity than other breeds. LIM showed the lowest dry matter content but the highest crude protein. LX and LIM had higher percentage and density of red muscle fiber than other breeds. Lipid oxidations were significantly lower in LIM than in QC, with the LX, SIM and JN having the intermediate values. Compared to other four breeds, QC provided the highest values of polyunsaturated fatty acids (PUFA), n-6 fatty acids and n-3 fatty acids. In conclusion, LIM scored better on most of meat quality characteristics; however, local breeds such as LX and QC also had better muscle fiber characteristics and better fatty acids composition. (Key Words: Breed, Beef Cattle, Meat Quality, Muscle Fiber Characteristic, Lipid Oxidation, Fatty Acids)
\end{abstract}

\section{INTRODUCTION}

Breed is an important factor that can influence meat quality in some ways including muscle structure and meat physiology (Sañudo et al., 2004; Waritthitham et al., 2010). Though local breeds have some advantage such as crude feed tolerance, high reproductive performance, low maintenance requirements, their growth performance and dressing percentage are low (Liu et al., 2006; Li et al., 2009). To improve growth performance and meat quality, China has imported some high producing cattle breeds such as Limousin and Simmental from other countries. Zhou et al. (2001) reported that crossbreeding could significantly improve Yellow Cattle meat productivity. Yang et al. (2007) also noted that the growth performance and carcass quality of Limousin $\times$ Qinchuan crossbreed F1 cattle were improved under local conditions. Luxi, Qinchuan, Jinnan, Limousin and Simmental are the most important local and imported cattle breeds in China. However, no information is available comparing the meat quality of these cattle breeds based on the same age and feed resources.

\footnotetext{
* Corresponding Author: Liping Ren. Tel: +86-10-6273-3799, Fax: +86-10-6282-9099, E-mail: renlp@cau.edu.cn Submitted Dec. 5, 2011; Accepted Feb. 22, 2012; Revised Mar. 7, 2012
}

The objective of this study was to compare meat quality characteristics of the imported breeds (Limousin and Simmtental) and local breeds (Luxi, Qinchuan and Jinnan) at the same age offered the same diet in China.

\section{MATERIALS AND METHODS}

\section{Animals and experimental design}

The experiment was conducted at China Agricultural University Beef Cattle Practical Education Base located in Daxing District, Beijing. Fifteen male calves of Limousin (LIM), Simmental (SIM), Qinchuan (QC) and thirteen male calves of Luxi (LX) and Jinnan (JN) born in around December 2007 were selected and transferred to the experimental base at 6 months old. After arriving in the experimental base, all the bulls were fed maize stalk silage, by-products such as soybean pomace and brewers dried grain and concentrate ad libitum until about 15 months. Management practices were applied equally to all calves. At the commencement of the finishing trail the weight of the bulls ranged from $236 \mathrm{~kg}$ to $387 \mathrm{~kg}$. Then all bulls were divided randomly into five breed groups and housed individually in stalls. During 105-d fattening period, the animals had the same total mixed ration ad libitum. The 
finishing period diet consisted of $440 \mathrm{~g}$ maize, $30 \mathrm{~g}$ cotton seed meal, $88 \mathrm{~g}$ soybean pomace, $110 \mathrm{~g}$ brewers dried grain, $300 \mathrm{~g}$ maize stalk silage and $32 \mathrm{~g}$ compound premix per $\mathrm{kg}$ dry matter. The nutrients composition were 11.1 metabolic energy MJ, $117 \mathrm{~g}$ crude protein, $400 \mathrm{~g}$ neutral detergent fiber, $196 \mathrm{~g}$ acid detergent fiber, $5.1 \mathrm{~g} \mathrm{Ca}, 3.0 \mathrm{~g} \mathrm{P}$ per kg dry matter. All procedures involving animals were conducted under approval of the China Agricultural University Institutional Animal Care and Use Committee.

\section{Sampling procedures}

Eight finished bulls selected randomly from each breed were slaughtered. Carcasses were chilled at 1 to $4^{\circ} \mathrm{C}$ for 24 h. To determine meat $\mathrm{pH}$, Subcutaneous fat and muscle color, texture, chemical composition, lipid oxidations, and fatty acid composition, the longissimus dorsi (ld) of each left half side was cut between the 12th and 13th rib, dissected, and sliced into steaks.

\section{Meat quality analysis}

Measurement of $\mathrm{pH}$ was recorded in ld muscle at the 12th rib level with a $\mathrm{pH}$ meter (Eutech Instruments, $\mathrm{pH}$ Spear, USA). Subcutaneous fat color and muscle color were estimated between 12 and 13 ribs after $1 \mathrm{~h}$ blooming at $4^{\circ} \mathrm{C}$ using a portable colorimeter (Minolta, CR400/410, Japan) based on $\mathrm{L}^{*}, \mathrm{a}^{*}, \mathrm{~b}^{*}$ in the CIELAB space. Chroma $\left(\mathrm{C}^{*}\right)$ and hue $\left(h^{*}\right)$ were calculated from the $a^{*}$ and $b^{*}$ values as:

$$
\mathrm{C}^{*}=\left(\mathrm{a}^{*} \times \mathrm{a}^{*}+\mathrm{b}^{*} \times \mathrm{b}^{*}\right)^{1 / 2} \text { and } \mathrm{h}^{*}=\arctan \mathrm{b} / \mathrm{a}^{*}
$$

One steak was cut into two blocks measuring $15 \times 15 \times 30$ $\mathrm{mm}$ and then suspended at $4^{\circ} \mathrm{C}$ for $48 \mathrm{~h}$ to calculate drip loss. Another steak was vacuum packed in a polyethylene bag and heated at $80^{\circ} \mathrm{C}$ until the internal temperature reached $70^{\circ} \mathrm{C}$ to calculate the cooking loss percentage. Then each sample provided six round strips $(1 \mathrm{~cm}$ diameter $)$ for Warner-Bratzler Shear Force (Salter Brecknell, Model 2356X, USA) test and the fiber paralleled to the longest dimension.

\section{Meat chemical composition analysis}

A $50 \mathrm{~g}$ sample of ld was freeze dried for the determination of dry matter (DM), protein, fat and ash contents using standard procedures (AOAC, 1985).

\section{Muscle fiber characteristics investigation}

The fresh steak was cut into cubes of $1 \mathrm{~cm}^{3}$ and stored at $-80^{\circ} \mathrm{C}$ for muscle fiber characteristics investigation. The nitro-blue tetrazolium technique was used to demonstrate succinic dehydrogenase activity situated in the mitochondria (Gauthier, 1969). Fibers were classified into red, intermediate and white according to the intensity of the staining reaction. The muscle fiber type percentage, muscle fiber diameter, and muscle fiber density were determined by digital camera (Nikon, TE2000-S, Japan) and Image Proplus analysis software.

\section{Lipid oxidation determination}

One steak about $20 \mathrm{~g}$ was homogenized and then stored at $-80^{\circ} \mathrm{C}$ for lipid oxidation determination. The homogenized meat was taken out and then stored at $4^{\circ} \mathrm{C}$ with air exposure. Meat samples were collected at $0,4,8$, 12, 24, 48 and $72 \mathrm{~h}$ for lipid oxidation determination.

Lipid oxidations were evaluated by the production of lipid hydroperoxides (PV) and thiobarbituric acid reactive substances (TBARS) according to the method of Richards and Dettmann (2003).

Determination of $P V$ : Approximately $0.3 \mathrm{~g}$ of the tissue was homogenized in $5 \mathrm{ml}$ of cold chloroform:methanol $(1: 1)$. Then $3.08 \mathrm{ml}$ of cold $0.5 \% \mathrm{NaCl}$ was added to separate the mixture into two phases. The mixture was then centrifuged at 3,297g (Beckman, J6M, USA) for $6 \mathrm{~min}$ at $4^{\circ} \mathrm{C}$. Two $\mathrm{ml}$ of the lower chloroform layer was removed and transferred to a tube using a glass syringe and $1.33 \mathrm{ml}$ of chloroform:methanol (1:1) was added to the $2 \mathrm{ml}$ sample. Then $25 \mu \mathrm{l}$ of $3.94 \mathrm{~mol} / \mathrm{L}$ ammonium thiocyanate and $25 \mu \mathrm{l}$ of $18 \mathrm{mmol} / \mathrm{L}$ iron (II) chloride were added to the tube, vortexing $4 \mathrm{~s}$ after each addition. The sample was then incubated at room temperature for $20 \mathrm{~min}$ and absorbance read at $500 \mathrm{~nm}$ (Keda, UV8500, China). A standard curve was constructed using cumene hydroperoxide and the concentration of lipid peroxide in the sample was expressed as $\mu \mathrm{mol}$ of lipid peroxides/(kg of muscle).

Determination of TBARS: On the day of analysis, a solution of $50 \%$ trichloroacetic acid (TCA) with $1.3 \%$ thiobarbituic acid (TBA) was prepared by mixing and heating to $65^{\circ} \mathrm{C}$ to dissolve solutes. A $1.2 \mathrm{ml}$ volume of the TCA-TBA reagent was the added to each sample $(0.1 \mathrm{~g})$ and the sample was mixed via inversion and heated at $65^{\circ} \mathrm{C}$ for $60 \mathrm{~min}$ (Guohua, HH-60, China). The sample was then centrifuged at $1,600 \mathrm{~g}$ for $5 \mathrm{~min}$ (Eppendorf centrifuge, 5411D, Germany). Absorbance of supernatants was read at $532 \mathrm{~nm}$ (Keda, UV8500, China). A standard curve was constructed using tetraethoxypropane and concentrations of TBARS in samples were expressed as $\mu \mathrm{mol}$ of TBARS/ $\mathrm{Tg}$ of muscle).

\section{Fatty acid analysis and calculations}

A $50 \mathrm{~g}$ sample of ld was freeze dried for the determination of fatty acid. Fatty acid methyl ester (FAME) synthesis was conducted according to O'Fallon et al. (2007). The fatty acid composition of FAME was determined by capillary GC on a SPTM-2560, $100 \mathrm{~m} \times 0.25 \mathrm{~mm} \times 0.20 \mu \mathrm{m}$ capillary column (Supelco, Bellefonte, PA, USA) installed on a Agilent 6890 GC (Agilent, Santa Clara, USA). The initial oven temperature was $140^{\circ} \mathrm{C}$, held for $5 \mathrm{~min}$, subsequently increased to $240^{\circ} \mathrm{C}$ at a rate of $4^{\circ} \mathrm{C} / \mathrm{min}$, and then held for 20 min. Helium was used as the carrier gas at 
Table 1. Comparison of meat traits of the five cattle breeds

\begin{tabular}{|c|c|c|c|c|c|c|c|}
\hline \multirow{2}{*}{ Item } & \multicolumn{5}{|c|}{ Breed $^{1}$} & \multirow{2}{*}{ SEM } & \multirow{2}{*}{$\mathrm{p}$} \\
\hline & LIM & SIM & LX & $\mathrm{QC}$ & $\mathrm{JN}$ & & \\
\hline \multicolumn{8}{|l|}{ Meat color $(24 \mathrm{~h})$} \\
\hline $\mathrm{L}^{*}$ & 38.92 & 35.80 & 38.45 & 36.32 & 36.95 & 1.065 & 0.195 \\
\hline$a^{*}$ & 19.81 & 19.52 & 20.52 & 18.64 & 20.57 & 0.927 & 0.336 \\
\hline$b^{*}$ & $9.96^{\mathrm{a}}$ & $9.11^{\mathrm{ab}}$ & $9.59^{\mathrm{a}}$ & $7.92^{\mathrm{b}}$ & $9.43^{\mathrm{ab}}$ & 0.633 & 0.092 \\
\hline $\mathrm{C}$ & 21.13 & 21.55 & 22.67 & 20.27 & 22.63 & 1.092 & 0.268 \\
\hline Hue & $28.06^{\mathrm{a}}$ & $24.95^{\mathrm{b}}$ & $24.90^{\mathrm{b}}$ & $22.67^{\mathrm{c}}$ & $24.57^{\mathrm{bc}}$ & 0.816 & 0.0005 \\
\hline \multicolumn{8}{|l|}{ Subcutaneous fat color ( $24 \mathrm{~h})$} \\
\hline $\mathrm{L}^{*}$ & 78.37 & 79.02 & 78.64 & 79.87 & 79.57 & 1.082 & 0.852 \\
\hline$a^{*}$ & 3.39 & 3.43 & 2.47 & 3.42 & 2.31 & 0.394 & 0.109 \\
\hline $\mathrm{b}^{*}$ & 7.34 & 6.89 & 6.24 & 6.04 & 6.15 & 0.422 & 0.156 \\
\hline $\mathrm{C}$ & 8.18 & 7.75 & 6.83 & 7.06 & 6.63 & 0.491 & 0.157 \\
\hline Hue & $64.32^{\mathrm{ab}}$ & $63.67^{\mathrm{ab}}$ & $68.73^{\mathrm{ab}}$ & $61.90^{\mathrm{b}}$ & $69.75^{\mathrm{a}}$ & 2.343 & 0.102 \\
\hline $\mathrm{pH}(24 \mathrm{~h})$ & $6.18^{\mathrm{a}}$ & $5.61^{\mathrm{b}}$ & $5.61^{\mathrm{b}}$ & $5.73^{\mathrm{b}}$ & $5.62^{\mathrm{b}}$ & 0.064 & 0.0001 \\
\hline Drip loss (24 h, \%) & 9.57 & 10.29 & 10.26 & 10.32 & 10.08 & 0.424 & 0.7012 \\
\hline Cooking loss (\%) & $26.99^{\mathrm{b}}$ & $29.38^{\mathrm{ab}}$ & $31.01^{\mathrm{a}}$ & $30.53^{\mathrm{a}}$ & $29.04^{\mathrm{ab}}$ & 1.026 & 0.0759 \\
\hline Warner-Bratzler-Shear (WBS, kg) & 4.67 & 5.36 & 4.39 & 5.29 & 5.15 & 0.416 & 0.4077 \\
\hline
\end{tabular}

Means in the same row with different superscripts are significantly different $(\mathrm{p}<0.05)$.

${ }^{1}$ LIM = Limousin; SIM = Simmtental; LX = Luxi; QC = Qinchuan; JN = Jinnan.

a flow rate of $0.5 \mathrm{ml} / \mathrm{min}$, and the column head pressure was $280 \mathrm{kPa}$. The injector and the detector were set at $250^{\circ} \mathrm{C}$ and $260^{\circ} \mathrm{C}$, respectively. The split ratio was $30: 1$. Fatty acids were identified by comparing their retention times with the fatty acid methyl standards (Ample, California, USA). Saturated fatty acids (SFA) were the sum of C15:0, C16:0, C17:0, C18:0, C20:0, and C22:0. Monounsaturated fatty acids (MUFA) were the sum of $\mathrm{C} 14: 1 \mathrm{n} 5, \mathrm{C} 16: 1 \mathrm{n} 7, \mathrm{C} 17: 1 \mathrm{n} 7, \mathrm{C} 18: 1 \mathrm{n} 9 \mathrm{t}, \mathrm{C} 18: 1 \mathrm{n} 9 \mathrm{c}$, and C20:1n9. Polyunsaturated fatty acids (PUFA) were the sum of C18:2n6t, C18:2n6c, C18:3n6, C18:3n3, C20:2, C20:3n6, $\mathrm{C} 20: 4 \mathrm{n} 6, \mathrm{C} 20: 5 \mathrm{n} 3$, and $\mathrm{C} 22: 6 \mathrm{n} 3$. N-6 fatty acids were the sum of C18:2n6t, C18:2n6c, C18:3n6, C20:3n6, and C20:4n6. N-3 fatty acids were the sum of C18:3n3, $\mathrm{C} 20: 5 \mathrm{n} 3$, and $\mathrm{C} 22: 6 \mathrm{n} 3$.

\section{Statistical analysis}

The effect of breed on meat characteristics, muscle fiber lipid oxidation products and fatty acids were subjected to one-way analysis of variance using Generalized Linear Models procedures of SAS (2000). The significance differences between least square group means were compared using the PDIFF test of SAS (2000).

\section{RESULTS}

\section{Comparison of meat quality traits}

Lightness $\left(\mathrm{L}^{*}\right)$, redness $\left(\mathrm{a}^{*}\right)$ and chroma (C) of ld muscle were similar among all cattle breeds (Table 1), however, yellowness $\left(b^{*}\right)$ was significantly lower in QC than in LIM and LX cattle breeds. The Hue value was significantly lower in QC, SIM, LX and JN than in LIM. Most of the subcutaneous fat colorimetric parameters did not differ significantly among the cattle breeds, except Hue which was lower in QC than in other cattle breeds. Drip loss and Warner-Bratzler-Shear (WBS) did not differ significantly among these breeds, while cooking loss and $\mathrm{pH}(24 \mathrm{~h})$ in LIM was the lowest and the highest, respectively among the tested cattle breeds.

\section{Comparison of meat chemical composition}

The proportion of dry matter was significantly lower in LIM than in other cattle breeds, while crude protein was the highest in LIM among the tested breeds (Table 2). No effect

Table 2. Comparison of chemical composition of the cattle breeds

\begin{tabular}{lccccccc}
\hline \multirow{2}{*}{ Item } & \multicolumn{3}{c}{ Breed $^{1}$} & \multirow{2}{*}{ SEM } & p \\
\cline { 2 - 6 } & LIM & SIM & LX & QC & JN & & 0.290 \\
Dry matter (\%) & $24.18^{\mathrm{b}}$ & $25.40^{\mathrm{a}}$ & $25.49^{\mathrm{a}}$ & $25.34^{\mathrm{a}}$ & $25.59^{\mathrm{a}}$ & 0.0051 \\
Crude protein (\% DM) & $88.73^{\mathrm{a}}$ & $85.53^{\mathrm{ab}}$ & $84.17^{\mathrm{b}}$ & $87.19^{\mathrm{ab}}$ & $84.48^{\mathrm{b}}$ & 1.232 & 0.0422 \\
Ether extract (\% DM) & 8.26 & 10.21 & 10.91 & 10.44 & 10.32 & 1.194 & 0.5754 \\
Ash (\% DM) & $3.69^{\mathrm{bc}}$ & $4.05^{\mathrm{abc}}$ & $4.90^{\mathrm{ab}}$ & $3.15^{\mathrm{c}}$ & $5.11^{\mathrm{a}}$ & 0.493 & 0.0261 \\
\hline
\end{tabular}

Means in the same row with different superscripts are significantly different $(\mathrm{p}<0.05)$.

${ }^{1}$ LIM = Limousin; SIM = Simmtental; LX = Luxi; QC = Qinchuan; JN = Jinnan. 
Table 3. Comparison of histological characteristics of muscle fiber of the five cattle breeds

\begin{tabular}{|c|c|c|c|c|c|c|c|c|}
\hline \multirow{2}{*}{ Item } & & \multicolumn{5}{|c|}{ Breed $^{1}$} & \multirow{2}{*}{ SEM } & \multirow{2}{*}{$\mathrm{p}$} \\
\hline & & LIM & SIM & LX & $\mathrm{QC}$ & $\mathrm{JN}$ & & \\
\hline \multirow[t]{3}{*}{ Myofiber type percentage } & $\mathrm{R}$ & $29.46^{\mathrm{a}}$ & $15.24^{\mathrm{b}}$ & $32.73^{\mathrm{a}}$ & $16.91^{\mathrm{b}}$ & $20.62^{\mathrm{b}}$ & 2.691 & 0.0001 \\
\hline & I & $26.54^{\mathrm{abc}}$ & $28.58^{\mathrm{ab}}$ & $24.02^{\mathrm{bc}}$ & $29.17^{\mathrm{a}}$ & $23.23^{\mathrm{c}}$ & 1.842 & 0.0313 \\
\hline & $\mathrm{W}$ & $44.00^{\mathrm{b}}$ & $56.16^{\mathrm{a}}$ & $43.24^{\mathrm{b}}$ & $53.90^{\mathrm{a}}$ & $56.14^{\mathrm{a}}$ & 2.899 & 0.0001 \\
\hline \multirow[t]{3}{*}{ Myofiber diameter } & $\mathrm{R}$ & $35.99^{b}$ & $36.55^{b}$ & $38.98^{\mathrm{b}}$ & $60.00^{\mathrm{a}}$ & $37.58^{\mathrm{b}}$ & 2.915 & 0.0001 \\
\hline & I & $41.49^{b}$ & $39.22^{b}$ & $41.42^{\mathrm{b}}$ & $61.10^{\mathrm{a}}$ & $42.19^{b}$ & 2.491 & 0.0001 \\
\hline & $\mathrm{W}$ & $49.47^{\mathrm{c}}$ & $49.46^{\mathrm{c}}$ & $59.27^{\mathrm{b}}$ & $67.80^{\mathrm{a}}$ & $47.94^{\mathrm{c}}$ & 2.808 & 0.0001 \\
\hline \multirow[t]{3}{*}{ Myofiber density } & $\mathrm{R}$ & $58.33^{\mathrm{ab}}$ & $32.41^{\mathrm{d}}$ & $67.59^{\mathrm{a}}$ & $36.36^{\mathrm{cd}}$ & $49.54^{\mathrm{bc}}$ & 6.808 & 0.0001 \\
\hline & I & $55.56^{\mathrm{ab}}$ & $62.04^{\mathrm{a}}$ & $48.15^{\mathrm{b}}$ & $54.04^{\mathrm{ab}}$ & $51.85^{\mathrm{ab}}$ & 4.582 & 0.1427 \\
\hline & $\mathrm{W}$ & $97.22^{b}$ & $121.30^{\mathrm{a}}$ & $87.96^{\mathrm{b}}$ & $98.99^{\mathrm{b}}$ & $125.00^{\mathrm{a}}$ & 8.822 & 0.0001 \\
\hline
\end{tabular}

Means in the same row with different superscripts are significantly different $(\mathrm{p}<0.05)$.

${ }^{1}$ LIM = Limousin; SIM = Simmtental; LX = Luxi; QC = Qinchuan; JN = Jinnan.

of breed on ether extract was recorded. The proportion of ash was significantly higher in JN and LX than in QC, but the mean values in LIM and SIM were intermediate to and did not differ significantly from the values of the LX and QC breeds.

\section{Comparison of muscle fiber characteristics}

The red muscle fiber (R) percentage of the ld was significantly higher in LX and LIM breeds than in other breeds (Table 3). Intermediate muscle fiber (I) percentage was significantly higher in QC than in JN, with the LIM, SIM and LX breeds taking the intermediate positions. White muscle fiber (W) percentage was significantly lower in LX and LIM breeds than in other cattle breeds. The diameters of $\mathrm{R}$, I and $\mathrm{W}$ muscle fibers were significantly larger in QC than in other cattle breeds. Red muscle fiber density was higher in LX and LIM breeds than in other breeds, whereas white muscle fiber in LX and LIM was lower than in other breeds. Intermediate muscle fiber density was lower in LX than in SIM, but the mean values in LIM, QC and JN were intermediate to and did not differ significantly from the values of the LX and SIM breeds.

\section{Comparison of lipid oxidation}

The lipid hydroperoxides were increased with the storage time at $4^{\circ} \mathrm{C}$ of air exposure for all the cattle breeds (Figure 1). A significant difference of lipid hydroperoxides among cattle breeds was observed. Lipid hydroperoxides

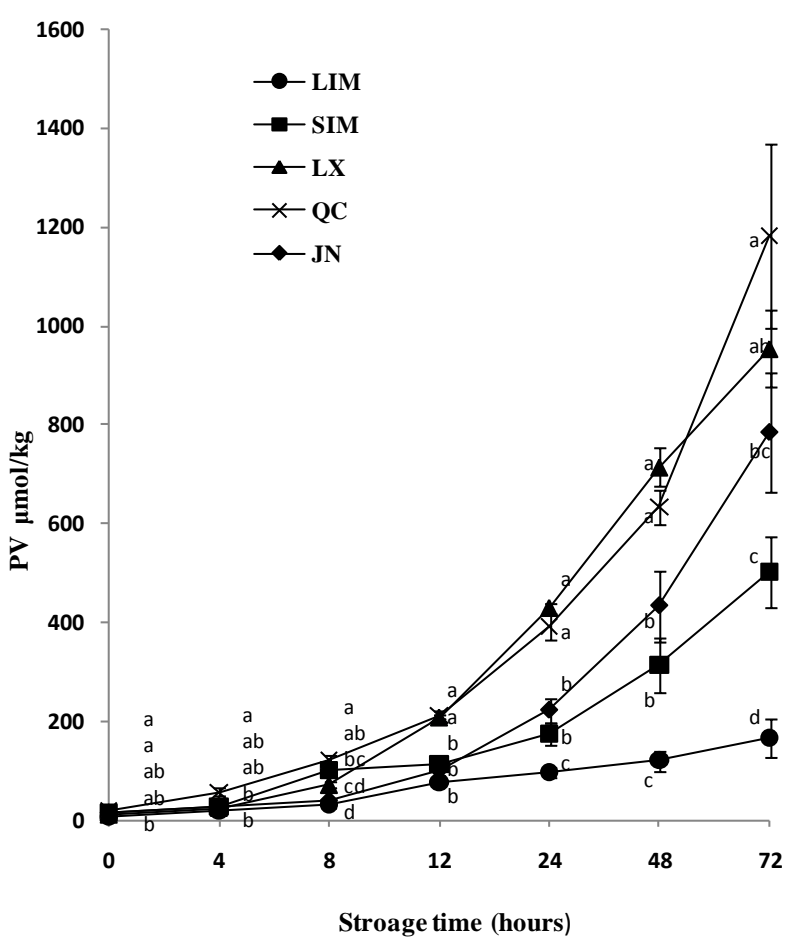

Figure 1. Comparison of lipid hydroperoxides at different times in the longissimus dorsi (ld) muscle of five cattle breeds $(\mu \mathrm{mol} / \mathrm{kg})(\mathrm{N}=$ 8). Data are presented as mean \pm SD. Values with different superscript letters are significantly different $(\mathrm{p}<0.05)$. 


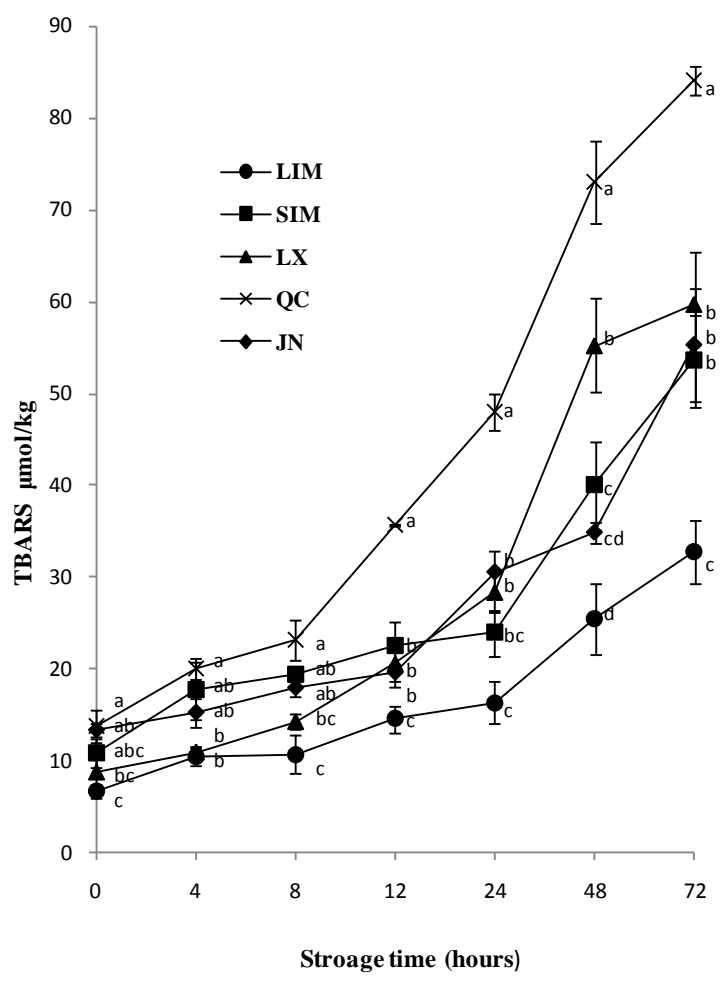

Figure 2. Comparison of TBARS at different times in the longissimus dorsi (ld) muscle of five cattle breeds $(\mu \mathrm{mol} / \mathrm{kg}) \quad(\mathrm{N}=8)$. Data are presented as mean $\pm \mathrm{SD}$. Values with different superscript letters are significantly different $(\mathrm{p}<0.05)$.

were significantly higher in QC compared with LIM, with the SIM, LX and JN taking the intermediate values from 0 to 8hours. From 12 to $72 \mathrm{~h}$, lipid hydroperoxides were lower in LIM than in QC and LX, with the SIM and JN taking the intermediate values.

Similar trends were obtained for TBARS (Figure 2). The TBARS were also increased with the storage time at $4^{\circ} \mathrm{C}$ for all the cattle breeds. The values of TBARS were significantly lower in LIM and LX than in QC from 0 to 8 hours. From 12 to 72 h, TABRS were significantly lower in LIM than in QC, with the LX, SIM and JN breeds having the intermediate positions.

\section{Comparison of fatty acids}

Values of fatty acids in the major fatty acid classes of these cattle breeds are presented in Table 4 . The total fatty acids, saturated fatty acid (SFA), and MUFA did not differ significantly among the five cattle breeds. Compared to other four breeds, QC had higher PUFA, n-6 fatty acids and $\mathrm{n}-3$ fatty acids. The value of $\mathrm{n}-6: \mathrm{n}-3$ ratio was significantly lower in QC and LIM than in JN, but the mean values in SIM and LX were intermediate to and did not differ significantly from the values of the QC, LIM and JN breeds.

\section{DISCUSSION}

\section{Meat quality traits}

Meat color is a further important determinant of visual appearance of meat (Chambaza et al., 2003) and can influence the purchasing decisions of the consumers (Mancini and Hunt, 2005). Brewer et al. (2001) reported that $\mathrm{L}^{*}$ value was most correlated to visual color, and using $\mathrm{L}^{*}$ in conjunction with $\mathrm{a}^{*}$ explained $69 \%$ of the variability in the visual pink color. Pigment content and oxidation state accounted for much of the variation in $a^{*}$ values (Mancini and Hunt, 2005; Waritthitham et al., 2010), while redox state and intramuscular fat content influenced $b^{*}$ value (Mancini and Hunt, 2005; Bispo et al., 2010; Waritthitham et al., 2010). Hue was negatively correlated to redness (Insausti et al., 1999). In term of muscle color, the five cattle breeds didn't differ in our study in the degree of lightness $\left(\mathrm{L}^{*}\right)$ and redness $\left(\mathrm{a}^{*}\right)$ and all of the values were in agreement with Chambaza et al. (2003), Vieira et al. (2007) and Muchenje et al. (2008). In the present study, most of the fat color parameters didn't differ among the cattle breeds. The values for $\mathrm{L}^{*}$ in subcutaneous fat were higher and for $b^{*}$ were lower than those reported by Vieira et al. (2007). All the cattle breeds had fine muscle and fat colors, especially, LIM and LX had better muscle color in the current study.

With an exception of LIM, the $\mathrm{pH}(24 \mathrm{~h})$ values of the other four cattle breeds were within the normal range and similar to the previous reports (Vieira et al., 2007; Muchenje et al., 2008; Bispo et al., 2010). Waritthitham et al. (2010) and Bispo et al. (2010) reported that pre-slaughter stress which leads to glycogen depletion may influence the 
Table 4. Comparison of fatty acids $(\mathrm{mg} / \mathrm{g})^{1}$ of five cattle breeds

\begin{tabular}{|c|c|c|c|c|c|c|c|c|}
\hline \multirow{2}{*}{ Fatty acid } & \multirow{2}{*}{ Structure } & \multicolumn{5}{|c|}{ Breed $^{2}$} & \multirow{2}{*}{ SEM } & \multirow{2}{*}{$\mathrm{p}$} \\
\hline & & LIM & SIM & LX & QC & $\mathrm{JN}$ & & \\
\hline Lauric & $\mathrm{C} 12: 0$ & 0.05 & 0.03 & 0.03 & 0.03 & 0.02 & 0.011 & 0.5627 \\
\hline Myristic & $\mathrm{C} 14: 0$ & 2.63 & 2.42 & 2.08 & 1.70 & 1.93 & 0.393 & 0.4336 \\
\hline Myristoleic & $\mathrm{C} 14: \ln 5$ & 0.55 & 0.49 & 0.41 & 0.27 & 0.34 & 0.100 & 0.2781 \\
\hline Pentadecanoic & $\mathrm{C} 15: 0$ & 0.26 & 0.28 & 0.24 & 0.26 & 0.24 & 0.036 & 0.9271 \\
\hline Palmitic & $\mathrm{C} 16: 0$ & 21.49 & 22.07 & 19.26 & 18.16 & 19.40 & 2.909 & 0.845 \\
\hline Palmitoleic & C16:1n7 & 2.91 & 2.36 & 2.20 & 2.03 & 2.26 & 0.440 & 0.6383 \\
\hline Heptadecanoic & $\mathrm{C} 17: 0$ & 0.64 & 0.65 & 0.62 & 0.59 & 0.61 & 0.078 & 0.9876 \\
\hline Cis-10-Heptadecenoic & $\mathrm{C} 17: \ln 7$ & 0.47 & 0.41 & 0.41 & 0.35 & 0.40 & 0.059 & 0.7008 \\
\hline Stearic & C18:0 & 13.32 & 14.05 & 14.02 & 14.85 & 13.90 & 1.706 & 0.9787 \\
\hline Elaidic & $\mathrm{C} 18: \ln 9 \mathrm{t}$ & 1.65 & 1.77 & 1.63 & 1.67 & 1.49 & 0.217 & 0.9267 \\
\hline Oleic & $\mathrm{C} 18 \mathrm{~s} \ln 9 \mathrm{c}$ & 27.73 & 30.86 & 25.66 & 22.68 & 26.12 & 3.876 & 0.6354 \\
\hline Linolelaidic & $\mathrm{C} 18: 2 \mathrm{n} 6 \mathrm{t}$ & 0.18 & 0.19 & 0.16 & 0.15 & 0.15 & 0.028 & 0.7552 \\
\hline Linoleic & $\mathrm{C} 18: 2 \mathrm{n} 6 \mathrm{c}$ & $3.63^{\mathrm{b}}$ & $3.67^{\mathrm{b}}$ & $4.08^{\mathrm{b}}$ & $4.77^{\mathrm{a}}$ & $3.86 \mathrm{~b}$ & 0.227 & 0.0059 \\
\hline Arachidic & C20:0 & $0.09^{\mathrm{a}}$ & $0.09^{\mathrm{a}}$ & $0.10^{\mathrm{a}}$ & $0.03^{\mathrm{b}}$ & $0.10^{\mathrm{a}}$ & 0.013 & 0.0011 \\
\hline$\gamma$-Linolenic & C18:3n6 & $0.07^{\mathrm{ab}}$ & $0.10^{\mathrm{a}}$ & $0.08^{\mathrm{ab}}$ & $0.03^{\mathrm{b}}$ & $0.10^{\mathrm{a}}$ & 0.022 & 0.0527 \\
\hline Eicosenoic & C20:1n9 & $0.13^{\mathrm{a}}$ & $0.13^{\mathrm{a}}$ & $0.12^{\mathrm{ab}}$ & $0.08^{\mathrm{b}}$ & $0.12^{\mathrm{ab}}$ & 0.015 & 0.0406 \\
\hline Linolenic & $\mathrm{C} 18: 3 \mathrm{n} 3$ & $0.13^{\mathrm{ab}}$ & $0.12^{\mathrm{ab}}$ & $0.13^{\mathrm{ab}}$ & $0.16^{\mathrm{a}}$ & $0.09^{\mathrm{b}}$ & 0.020 & 0.0693 \\
\hline Eicosadienoic & C20:2 & $0.16^{\mathrm{ab}}$ & $0.22^{\mathrm{a}}$ & $0.10^{\mathrm{b}}$ & $0.08^{\mathrm{b}}$ & $0.11^{\mathrm{b}}$ & 0.036 & 0.0462 \\
\hline Behenic & $\mathrm{C} 22: 0$ & 0.08 & 0.09 & 0.12 & 0.05 & 0.1 & 0.032 & 0.5387 \\
\hline Eicosatrienoic & $\mathrm{C} 20: 3 \mathrm{n} 6$ & $0.03^{\mathrm{b}}$ & $0.03^{\mathrm{b}}$ & $0.05^{\mathrm{b}}$ & $0.26^{\mathrm{a}}$ & $0.06^{\mathrm{b}}$ & 0.004 & 0.0004 \\
\hline Arachidonic & $\mathrm{C} 20: 4 \mathrm{n} 6$ & $0.45^{\mathrm{b}}$ & $0.46^{\mathrm{b}}$ & $0.62^{\mathrm{b}}$ & $1.01^{\mathrm{a}}$ & $0.58^{\mathrm{b}}$ & 0.084 & 0.0002 \\
\hline Eicosapentaenoic & $\mathrm{C} 20: 5 \mathrm{n} 3$ & 0.11 & 0.1 & 0.08 & 0.1 & 0.09 & 0.044 & 0.9815 \\
\hline Docosahexaenoic & $\mathrm{C} 22: 6 \mathrm{n} 3$ & $0.26^{\mathrm{ab}}$ & $0.2^{\mathrm{b}}$ & $0.14^{\mathrm{b}}$ & $0.61^{\mathrm{a}}$ & $0.18^{\mathrm{b}}$ & 0.014 & 0.1339 \\
\hline $\mathrm{SFA}^{3}$ & & 38.56 & 39.69 & 36.47 & 35.68 & 35.27 & 4.586 & 0.9506 \\
\hline MUFA $^{4}$ & & 33.44 & 36.02 & 30.44 & 26.78 & 29.65 & 4.183 & 0.5808 \\
\hline PUFA $^{5}$ & & $5.01^{\mathrm{b}}$ & $5.05^{\mathrm{b}}$ & $5.41^{\mathrm{b}}$ & $6.96^{\mathrm{a}}$ & $5.06^{\mathrm{b}}$ & 0.320 & 0.0004 \\
\hline$n-6^{6}$ & & $4.35^{\mathrm{b}}$ & $4.43^{\mathrm{b}}$ & $4.98^{\mathrm{b}}$ & $6.19^{\mathrm{a}}$ & $4.65^{\mathrm{b}}$ & 0.286 & 0.0004 \\
\hline$n-3^{7}$ & & $0.5^{\mathrm{ab}}$ & $0.39^{\mathrm{b}}$ & $0.33^{\mathrm{b}}$ & $0.8^{\mathrm{a}}$ & $0.31^{\mathrm{b}}$ & 0.112 & 0.0230 \\
\hline$n-6: n-3$ & & $12.31^{\mathrm{b}}$ & $18.14^{\mathrm{ab}}$ & $18.7^{\mathrm{ab}}$ & $8.93^{\mathrm{b}}$ & $22.99^{\mathrm{a}}$ & 3.369 & 0.0339 \\
\hline Total & & 77.00 & 80.75 & 72.31 & 69.42 & 69.98 & 8.884 & 0.8363 \\
\hline
\end{tabular}

${ }^{1}$ Milligrams per gram of freeze-dried tissue.

${ }^{2}$ LIM = Limousin; SIM = Simmtental; LX = Luxi; QC = Qinchuan; JN = Jinnan.

${ }^{3} \mathrm{SFA}=\mathrm{C} 12: 0+\mathrm{C} 14: 0+\mathrm{C} 15: 0+\mathrm{C} 16: 0+\mathrm{C} 17: 0+\mathrm{C} 18: 0+\mathrm{C} 20: 0+\mathrm{C} 22: 0 .{ }^{4} \mathrm{MUFA}=\mathrm{C} 14: 1 \mathrm{n} 5+\mathrm{C} 16: \ln 7+\mathrm{C} 17: 1 \mathrm{n} 7+\mathrm{C} 18: 1 \mathrm{n} 9 \mathrm{t}+\mathrm{C} 18: 1 \mathrm{n} 9 \mathrm{c}+\mathrm{C} 20: 1 \mathrm{n} 9$.

${ }^{5} \mathrm{PUFA}=\mathrm{C} 18: 2 \mathrm{n} 6 \mathrm{t}+\mathrm{C} 18: 2 \mathrm{n} 6 \mathrm{c}+\mathrm{C} 18: 3 \mathrm{n} 6+\mathrm{C} 18: 3 \mathrm{n} 3+\mathrm{C} 20: 2+\mathrm{C} 20: 3 \mathrm{n} 6+\mathrm{C} 20: 4 \mathrm{n} 6+\mathrm{C} 20: 5 \mathrm{n} 3+\mathrm{C} 22: 6 \mathrm{n} 3$.

${ }^{6} \mathrm{n}-6=\mathrm{C} 18: 2 \mathrm{n} 6 \mathrm{t}+\mathrm{C} 18: 2 \mathrm{n} 6 \mathrm{c}+\mathrm{C} 18: 3 \mathrm{n} 6+\mathrm{C} 20: 3 \mathrm{n} 6+\mathrm{C} 20: 4 \mathrm{n} 6 .{ }^{7} \mathrm{n}-3=\mathrm{C} 18: 3 \mathrm{n} 3+\mathrm{C} 20: 5 \mathrm{n} 3+\mathrm{C} 22: 6 \mathrm{n} 3$.

ultimate muscle $\mathrm{pH}$. However, all the cattle in this study were kept in the same environment at the abattoir over night, so it may be not the pre-slaughter stress factor that led to the higher $\mathrm{pH}$ values $24 \mathrm{~h}$ of LIM meat. The $\mathrm{pH}$ decline of meat was influenced by the rate of muscle cooled (Hwang and Thompson, 2001) and the muscle temperature decline was affected by carcass weight during chilling (Pike et al., 1993). So the higher $\mathrm{pH}$ values at $24 \mathrm{~h}$ in LIM may be ascribed to their heavier carcass weights.

According to Hur et al. (2009), high pH was closely related to high water-holding capacity. LIM cattle had better water-holding capacity than that of other cattle breeds in the present study, this may be due to their higher $\mathrm{pH}$ values.
However, Hwang et al. (2010) reported that there were no significant differences in drip loss among three parts of muscle, although ld muscle had a higher $\mathrm{pH}(24 \mathrm{~h})$ compared to the other muscles. Thus a further mechanism study is needed to clarify the relationship between $\mathrm{pH}$ and water holding capacity.

\section{Meat chemical composition}

Except for ether extract, there was a breed effect on meat chemical composition in the present study, which agrees with Muchenje et al. (2008) and Strydom et al. (2001). The chemical composition results were similar to the reports by Muchenje et al. (2008) and Waritthitham et al. 
(2010). However, the dry matter content was lower than that reported by Vieira et al. (2007) in which all the adults steers' dry matter composition were higher than $27 \%$ at 42 months old, so the difference may be due to their different slaughter age or hormone effect.

\section{Muscle fiber characteristics}

Waritthitham et al. (2010) and Hoving-Bolink et al. (1999) reported that breed influenced the meat tenderness by affecting collagen content and myofibrillar structure of muscle. However, some other studies carried out by Muchenje et al. (2008), Vieira et al. (2007) and Chambaza et al. (2003) showed that no differences in the tenderness of the meat among cattle breeds were detected. In the present study, the Warner-Bratzler-Shear (WBS) values were similar among all the cattle breeds and between $3.5 \mathrm{~kg}$ and $6 \mathrm{~kg}$. According to Bruce, Stark, and Belilken (2004), all the meat could be classified as of average toughness.

It has been indicated that the red muscle has a higher content of oxidative enzymes and mitochondria than does white muscle (Dubowitz and Everson Pearse, 1960; Lee et al., 2010). Gauthier (1969) demonstrated that the red portion of the muscle was composed predominantly of red (52\%) and intermediate (40\%) fibers. The results in the present study showed a similar trend, in which LIM and LX had relative better muscle color with higher percentage of red and intermediate muscle fibers. Strydom et al. (2000) reported that there were significant positive within-breed relationships between muscle tenderness and intermediate fiber percentage. Increasing the proportion of slow-twitch type I fibers percentage and area had been reported to improve tenderness in cattle (Maltin et al., 1998; Strydom et al., 2000; Hwang et al., 2010). In this study, though LX and LIM breeds had a higher percentage and density of red and intermediate fibers there were no significant differences in WBS values compared to that of the other cattle breeds, although the two cattle breeds had relative lower WBS values.

\section{Lipid oxidation and fatty acids}

Lipid oxidation was a leading cause of quality deterioration in meat and meat products (Hur et al., 2009). As Warren et al. (2008) reported, this study also found that breed had an effect on lipid oxidation. The PV and TBARS in LIM were significantly lower than in QC, which indicated that LIM cattle had better antioxidant ability. Berruga et al. (2005) suggested that lipid oxidation promoted oxymyoglobin oxidation and was significantly negatively correlated with redness. In this study, QC cattle also showed a relative lower redness, which agrees with the previous study. Skeletal muscle was susceptible to oxidative deterioration due to a combination of lipid oxidation catalysts and membrane lipid systems that were high in unsaturated fatty acids (Chan and Decker, 1994). Breed has an effect on fatty acids composition in muscle (Holló et al., 2001; Dance et al., 2009; Juárez et al., 2009). In this study, QC had the highest PUFA values among the five breeds, which should lead to lipid oxidation occurring more easily in this breed than in other breeds. However, an increase in PUFA and lower n-6:n-3 ratios are desirable for human health. If some antioxidative materials such as $\alpha$-tocopherol and $\beta$-carotene were added in the diet, the lipid oxidation characteristics of QC meat might be improved.

\section{CONCLUSIONS}

In this study, no effect of breed on WBS, crude extract and most of the muscle and fat color parameters was recorded. However, LX and LIM showed better muscle fiber characteristics and LIM cattle also had better water holding capacity and antioxidant ability, so all these traits in the two cattle breeds are advantages for extending meat shelf life. QC had the lowest antioxidant ability among the five cattle breeds, which should be due to the higher composition of polyunsaturated fatty acids in this breed.

\section{ACKNOWLEDGEMENTS}

This research is financed by China National Supporting Project (No. 2006BAD12B02) and the Earmarked Fund for Modern Agro-Industry Technology Research System (Beef Cattle and Yaks, CARS-38).

\section{REFERENCES}

AOAC. 1985. Official methods of analysis (16th ed.). Washington, DC: Association of Official Analytical Chemists.

Berruga, M. I., H. Vergara and L. Gallego. 2005. Influence of packaging conditions on microbial and lipid oxidation in lamb meat. Small Rumin. Res. 57:257-264.

Bispo, E., L. Monserrat, L. González, D. Franco and T. Moreno. 2010. Effect of weaning status on animal performance and meat quality of Rubia Gallega calves. Meat Sci. 86:832-838.

Brewer, M. S., L. G. Zhu, B. Bidner, D. J. Meisinger and F. K. McKeith. 2001. Measuring pork color: effects of bloom time, muscle, $\mathrm{pH}$ and relationship to instrumental parameters. Meat Sci. 57:169-176.

Bruce, H. L., J. L. Stark and S. L. Beilken. 2004. The effects of finishing diet and postmortem ageing on the eating quality of the M. longissimus thoracis of electrically stimulated Brahman steer carcasses. Meat Sci. 67:261-268.

Chambaza, A., M. R. L. Scheeder, M. Kreuzer and P. A. Dufeya. 2003. Meat quality of Angus, Simmental, Charolais and Limousin steers compared at the same intramuscular fat content. Meat Sci. 63:491-500.

Chan, K. M. and E. A. Decker. 1994. Endogenous skeletal muscle antioxidants. Crit. Rev. Food Sci. Nutr. 34:403-426.

Dance, L. J. E., K. R. Matthews and O. Doran. 2009. Effect of 
breed on fatty acid composition and stearoyl-CoA desaturase protein expression in the Semimembranosus muscle and subcutaneous adipose tissue of cattle. Livest. Sci. 125:291-297.

Dubowitz, V. and A. G. Everson Pearse. 1960. A comparative histochemical study of oxidative enzyme and phosphorylase activity in skeletal muscle. Histochem. Cell Biol. 2:105-117.

Gauthier, G. F. 1969. On the relationship of ultrastructural and cytochemical features to color in mammalian skeletal muscle. Z. Zellforsch. Mikrosk. Anat. 95:462-482.

Holló, G., J. Csapó, E. Szücs, J. Tözsér, I. Repa and I. Holló. 2001. Influence of breed, slaughter weight and gender on chemical composition of beef. Part 2. Fatty acid compos ition of fat in rib samples. Asian-Aust. J. Anim. Sci. 14:1719-1723.

Hoving-Bolink, A. H., W. J. A. Hanekamp and P. Walstra. 1999. Effects of sire breed and husbandry system on carcass, meat and eating quality of Piemontese and Limousin crossbred bulls and heifers. Livest. Prod. Sci. 57:273-278.

Hur, S. J., G. B. Park and S. T. Joo. 2009. Eúffect of storage temperature on meat quality of muscle with different fiber type composition from Korean native cattle (Hanwoo). J. Food Qual. 32:315-333.

Hwang, I. H. and J. M. Thompson. 2001. The interaction between $\mathrm{pH}$ and temperature decline early postmortem on the calpain system and objective tenderness in electrically stimulated beef longissimus doris muscle. Meat Sci. 58:167-174.

Hwang, Y. H., G. D. Kima, J. Y. Jeong, S. J. Hur and S. T. Joo. 2010. The relationship between muscle fiber characteristics and meat quality traits of highly marbled Hanwoo (Korean native cattle) steers. Meat Sci. 86:456-461.

Insausti, K., M. J. Beriain, A. Purroy, P. Alberti, L. Lizaso and B. Hernandez. 1999. Color stability of beef from different Spanish native cattle breeds stored under vacuum and modified atmosphere. Meat Sci. 53:241-249.

Juárez, M., O. Polvillo, M. D. Gómez, M. J. Alcalde, F. Romero and M. Valera. 2009. Breed effect on carcass and meat quality of foals slaughtered at 24 months of age. Meat Sci. 83:224-228.

Lee, S. H., S. T. Joo and Y. C. Ryu. 2010. Skeletal muscle fiber type and myofibrillar proteins in relation to meat quality. Meat Sci. 86:166-170.

Li, S. L. 2009. Overview on the production state of young white beef at home and abroad. J. Dairy Sci. Technol. 32:201-204.

Liu, B., H. Chen, X. Y. Lan, Z. Q. Zhang and R. F. Zhang. 2006. Research on heterosis and growth performance in Qinchuan and its hybrids. Chinese J. Anim. Sci. 42:1-4.

Maltin, C. A., K. D. Sinclair, P. D. Warriss, C. M. Grant, A. D. Porter, M. I. Delday and C. C. Warkup. 1998. The effects of age at slaughter, genotype and finishing system on the biochemical properties, muscle fiber type characteristics and eating quality of bull beef from suckled calves. Anim. Sci. 66: 341-348.
Mancini, R. A. and M. C. Hunt. 2005. Current research in meat color. Meat Sci. 71:100-121.

Muchenje, V., K. Dzama, M. Chimonyo, J. G. Raats and P. E. Strydom. 2008. Meat quality of Nguni, Bonsmara and Aberdeen Angus steers raised on natural pasture in the Eastern Cape, South Africa. Meat Sci. 79:20-28.

O'Fallon, J. V., J. R. Busboom, M. L. Nelson and C. T. Gaskins. 2007. A direct method for fatty acid methyl ester synthesis: Application to wet meat tissues, oils, and feed stuffs. J. Anim. Sci. 85:1511-1521.

Pike, M. M., T. P. Ringkob, D. D. Beekman, Y. O. Koh and W. T. Gerthoffer. 1993. Quadratic relationship between early-postmortem glycolytic rate and beef tenderness. Meat Sci. 34:1326.

Richards, M. P. and M. A. Dettmann. 2003. Comparative analysis of different hemoglobins: autoxidation, reaction with peroxide, and lipid oxidation. J. Agric. Food Chem. 51:3886-3891.

Sañudo, C., B. Panea, J. L. Olleta, Monson, I. Sierra, P. Albertí, P. Ertbjerg, M. Chistiansen, S. Gigli, S. Failla, A. Gaddini, J. F. Hocquette, R. Jailer, G. R. Nute and J. L. Williams. 2004. Carcass quality of several European cattle breeds preliminary results. Proceedings of 50th International Congress of Meat Science and Technology (pp. 516-518). 8th-13th August, Helsinki, Finland.

Strydom, P. E., R. T. Naudé, M. F. Smith, A. Kotzé, M. M. Scholtz and J. B. van Wyk. 2001. Relationships between production and product traits in subpopulations of Bonsmara and Nguni cattle. S. Afr. J. Anim. Sci. 31:181-194.

Strydom, P. E., R. T. Naude, M. F. Smith, M. M. Scholtz and J. B. van Wyk. 2000. Characterisation of indigenous African cattle breeds in relation to meat quality traits. Meat Sci. 55:79-88.

Vieira, C., A. Cerdeño, E. Serrano, P. Lavín and A. R. Mantecón. 2007. Breed and ageing extent on carcass and meat quality of beef from adult steers (oxen). Livest. Sci. 107:62-69.

Warren, H. E., N. D. Scollan, G. R. Nute, S. I. Hughes, J. D. Wood and R. I. Richardson. 2008. Effects of breed and a concentrate or grass silage diet on beef quality in cattle of 3 ages. II: Meat stability and flavor. Meat Sci. 78:270-278.

Waritthitham, A., C. Lambertz, H. J. Langholz, M. Wicke and M. Gauly. 2010. Assessment of beef production from Brahman $\times$ Thai native and Charolais $\times$ Thai native crossbred bulls slaughtered at different weights. II: Meat quality. Meat Sci. 85: 196-200.

Yang, X. B., H. Chen, L. S. Hua, Q. Yang and B. Liu. 2007. Effects analysis of two cattle pupolations in the west of China crossed by Limousin cattle. Acta agric. boreli-occidentalis Sinica 16:55-58.

Zhou, G. H., L. Liu, X. L. Xiu, H. M. Jian, L. Z. Wang, B. Z. Sun and B. S. Tong. 2001. Productivity and carcass characteristics of pure and crossbred Chinese Yellow Cattle. Meat Sci. 58: 359-362. 